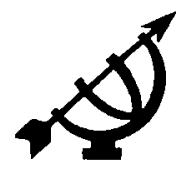

\title{
A dilemma in South African vocational guidance - and a possible solution
}

\author{
J.L. Marais \& J.L. van der Walt \\ Graduate School of Education \\ Faculty of Education \\ Potchefstroomse Universiteit vir $\mathrm{CHO}$ \\ POTCHEFSTROOM \\ E-mail: dopjlvdw@puknet.puk.ac.za \\ Abstract
}

\begin{abstract}
A dilemma in South African vocational guidance - and a possible solution
The dilemma in vocational guidance in the new democratic South Africa is clear. The rapidly changing social, demographic and economic features of life in South Africa require the immediate provision of culturally relevant vocational services to historically disadvantaged individuals and groups services which have been as yet non-existent because of the previous systematic and structural exclusion of persons of colour from the development of relevant vocational guidance tests and procedures.
\end{abstract}

In this article the authors suggest the implementation of self-help vocational guidance instruments (SHI's) as a possible solution to the dilemma. An example of a self-constructed $\mathrm{SHI}$ is given as an illustration of how teachers can construct self-help instruments for their schools.

\section{The dilemma}

Changing social, economic and political conditions in South Africa since the first country-wide democratic elections in 1994 have called for different approaches to labour, education, training and development, and also to vocational guidance. Such transitions are not unique to South Africa (cf. Skillen's [1987] reference to the ramifications of the 1840 transition from church to public/secular schools in the USA). The populations of education institutions have become more diverse, reflecting more than ever the racial and gender composition of the country's population. In line with universal tendencies, the workplace has also changed dramatically, i.e. from a manufacturing to a knowledge and information-based industry - to such an extent, says Goudzwaard (1997: 
43), that creation is groaning under the fantastic plans to expand economies and technologies to the highest possible limits. Even the individuals whom vocational counsellors previously had to serve have changed. The general group of young people with relatively stable and predictable futures in steady jobs has changed to insecure individuals facing an uncertain future.

The post-1994 economic and political transformation has changed the demographic features of South Africa dramatically. Urbanization, loss of employment, large scale redeployment of workers in formerly relatively stable occupations, changes in employment patterns and the recognition of the employment needs of the previously disadvantaged people of colour have all emphasized the need for vocational guidance to adapt to new circumstances (Marais, 1999:2-6). Despite these changes, much of what we do in education is unconsciously preparing the young to live in the world in which the previous generation grew up in, instead of preparing young people for the third millennium. Apropos to this, Sine $(1997: 25)$ remarks the following about conditions in the USA: "I have seen little in ... education that is intentionally designed to enable students to anticipate and creatively respond to the challenges of tomorrow's world".

The changes that have already taken place since 1994 are likely to be perpetuated well into the twenty-first century. South African society will remain increasingly multi-ethnic and multi-cultural.

The substantial improvement in the educational and vocational opportunities for people of colour implies the need for more and more efficient vocational guidance. If South Africa is to become an efficient international role-player, the development of its human resources will have to improve. This implies inter alia the more effective provision of information about career options, employment opportunities, and the most effective ways of accessing education, training and development opportunities (Van der Westhuizen et al., 1999:103-105).

This viewpoint, however, presents a dilemma. Our knowledge base about the development of population groups that have been systematically and structurally discriminated against is very restricted. Research results generally available are those on white minority groups in South Africa, such as the white hetero-sexual middle class youth (Hackett \& Byars, 1996:322-338; Chartrand \& Rose, 1996:341-350).

There is a danger that in tackling the back-log in vocational guidance for the previously disadvantaged people of colour, culturally-biased instruments, techniques and procedures will be followed, in the process doing 
further damage to the clients involved as well as to the image of vocational guidance as a respected profession.

The dilemma of having insufficient expert knowledge about such historically disadvantaged groups also has an ethical side. Korman (1974:443) warns that the provision of "professional services to persons of cultural diverse backgrounds by persons not competent in understanding and providing professional services to such groups shall be considered unethical". This opinion is widely supported (inter alia by Gysbers et al., 1998:39; Hernández \& Morales, 1999:45-50; Clearly, 1968:115).

There is an obvious need for culturally sensitive services to replace the culturally biased measuring instruments which have been standardized for white people (Fouad, 1993). Test bias as a problem has attracted much interest and attention, also in the USA, because of concern about the treatment of minority groups (Hernández \& Morales, 1999:45-50; Clearly, 1968:115).

Test bias can also be viewed as the phenomenon where certain identifiable groups of persons tested, for reasons that have nothing to do with the characteristic that a specific test is supposed to measure, gain higher or lower ratings on the relevant test or parts of the test. A mere difference in test averages between sub-groups in the norm population is not proof of test bias (HSRC, 1989:40-42).

Vocational guidance instruments and procedures are also regarded as biased and unfair if they do not provide for critical variables such as unsettledness due to migration, race discrimination and poverty. The provision of truly ethical vocational guidance which has the welfare of the target group or individual at heart should therefore be placed within the relevant socio-cultural context (cf. Sue \& Sue, 1990).

The dilemma in vocational guidance in the new democratic South Africa is clear. The rapidly changing social, demographic and economic features of life in South Africa require the immediate provision of culturally relevant vocational services to historically disadvantaged individuals and groups. The question is: how can this impasse be overcome?

We suggest the implementation of self-help vocational guidance instruments as a possible solution to the dilemma. In the following sections of this article we briefly glance back at the history of vocational guidance in South Africa to determine the cause of the dilemma and to see whether there are any resources available for the self-help instruments that we suggest. We then develop a number of criteria against which the suitability of a solution to the dilemma can be measured, and then suggest a few guidelines for the development of a self-help instrument 


\section{The cause of the dilemma}

We assume that colonialism and the apartheid ideology have been sufficiently identified as the general causes of the educational malaise in South Africa. This is the background and context of our discussion.

Vocational guidance can be traced back to ancient Greek civilizations with their emphasis on the development of human potential (Gibson \& Mitchell, 1995:4). Parsons' book On choosing a vocation (1909) supplied vocational guidance with a much needed scientific base. He emphazises the importance of a person understanding his/her own personality, skills and aptitudes well, and of aligning such self-knowledge with insight into career opportunities (Naude \& Bodibe, 1986:2; Landsberg, 1996:1; Kruger, 1995:34-35; Herr \& Cramer, 1996:8-12)

Subsequent developments in the fields of testing, research (cf. questionnaires), the education of learners with special needs, mental health, learning theory, developmental education and learning problems enabled vocational guidance take great strides forward (Fagan \& Wise, 1994:2528)

Education in South Africa has always been modelled on systems and practices in the colonizing mother-countries, and invariably targeted the needs of white colonists.

The earliest forms of vocational guidance in South Africa focused on persons who had already left school. With the advent of more differentiated schools (industrial, technical, arts, academic) from the 1950s onwards, there was a need to guide learners towards a sensible school choice, and concomitantly, a career choice (Naude \& Bodibe, 1986:3, Liebetrau, 1987:3). This differentiated approach was firmly entrenched in the Act on National Education Policy (Act 39 of 1967), an approach which emphasized the significance of repeated appropriate career choices for the purpose of leading a fulfilled and successful life (Jacobs et al., 1988:58). Vocational guidance, as a form of education, was instrumental in aiding and enabling learners to make such choices (Barnardt, 1971:15).

Because of the systematic implementation of apartheid education (19481994), relatively great differences gradually became part of the provision of vocational guidance in the different sub-systems (Raad vir Geesteswetenskaplike Navorsing, 1984; Naude \& Bodibe, 1986:3). Vocational guidance was gradually introduced to black people from 1984 onwards, but has up to now rarely met the requirements and expectations of the Human Sciences Research Council (Naude \& Bodibe, 1986:3-5). 
Despite all such constraints, the provision of vocational guidance had the same basic structure everywhere: it consisted of psychological counselling as well as school guidance (Isaacson, 1984:145-150; Kruger, 1995: 1-7). Psychometric testing and evaluation are done by practitioners registered with the South African Medical and Dental Council. A large percentage of the school population unfortunately still does not have access to these services, resulting in a lack of self-knowledge and selfunderstanding, which are prerequisites for successful school and career choices. The problem of practitioners applying assessment instruments with which they are familiar and which they feel "work for them", to the exclusion of newer and more appropriate instruments (Herr \& Cramer, 1996:652-660), however, still exists

Concerns have been raised in the past about the abuse and excessive use of psychometric testing (Joubert, 1983:48; Jacobs et al., 1988:217; Gysbers et al., 1998:12). The Green Paper on Education and Training (South Africa, 1998) and Quality Education for All, (South Africa, 1997) recent policy documents - also warn against excessive testing.

With regard to the dilemma in vocational guidance in South Africa (cf section 1), it has become clear that vocational guidance, such as there had been and still is, does not satisfy the needs of South African learners. Herr and Cramer (1996:433) summarize the dilemma as follows: "Vocational guidance has been seen for too long as useful to only a highly restricted sample of the total learner population rather than to all or most learners". Energy and expertise ought now to be expended to re-conceptualize and develop a totally new model or solution which has the potential of satisfying the needs of most individual learners and/or groups

One needs hardly stress the point with educators and vocational guidance counsellors that the full in-born potential of each and every learner that has been entrusted to us should be identified and optimized. Not only does South Africa need it for the growth of its economy and the prosperity of its people; it is a deeply rooted need of all people, all created in the image of their Creator, all with inherent potential, all with a purpose in life, i.e. to serve and honour God in and through their work and deeds. No man or woman can achieve this on his or her own; everyone needs guides, mentors, educators, advisors, counsellors - and this is why vocational guidance is accorded such an important place in the process of enabling and "discipling" learners as educands.

Every human being is created in the image of God (imago Del), and as such was created for a specific purpose as well as with the potential to actualize this purpose or life-goal. Although some of this inherent 
potential can come to fruition through self-education (the "self-made" man or woman), it can only be realized in full under the caring and persistent efforts of an educator, or a whole series of educators. Education is required to assist and lead us to fulfil our purpose in life, which in the case of Christian educators and educands, is seen as to love, honour and to serve the Lord with all our might, and to love and serve our fellow human beings as we love and serve ourselves. Guidance, as a rather special way of educating (equipping) the educand, plays a significant role in all these processes.

Guidance as a form of education should "empower" the youth for their task and calling in life, i.e. should equip them for their life-task (Van Dyk, 1997:35 ff.) Educators, including guidance specialists, have an obligation to prepare young people to deal with the new realities of a global society in which they are competing with other people all over the world. However, this preparation should not be for the world as it is in its broken (imperfect) state, but for a world that can improve by the power of the Gospel of Jesus Christ (Sine, 1997:39). This stance is emphasized by Walsh (1997:11): "Christian education in precarious times needs to be prophetic in character, criticizing the forces that render us numb and energising young people to an alternative way of living in this world, subject to an alternative sovereignty".

If, as is presently the case in South Africa, such special and specialized forms of education are not available, responsible guidance counsellors and educationists have to come forward with creative and innovative solutions. The solution must also be financially viable and relatively simple to administer in order to meet the needs and requirements of even the most far-flung communities (Marais, 1999:10).

In the following section we discuss a possible solution in more particular.

\section{A possible solution: self-help instruments (SHI's)}

We concur with Sue and Sue (1990) that vocational services should be provided in appropriate cultural contexts if they are to be regarded as ethical. Cultural variation should be seen as a reality and be provided for; the rigid and uniform application of supposedly universal constructs and instruments should be avoided if all the needs of all the clients (i.e. learners) are to be accommodated. Clients should be assisted, say Fouad and Bingham (1995), not to all make the same choices but to make career choices that are culturally appropriate.

Self-help instruments meet these requirements, as well as other criteria which we outline below. The application of such instruments is relatively 
J.L. Marais \& J.L van der Walt

new to South Africa but have been tried and tested in several other countries (Kok, 1995). A self-help instrument (SHI) is a non-standardized questionnaire, and therefore complies with tests of validity, reliability and generalizability in unique ways (Jacobs, 1981:14). An SHI is completed by the learner, allowing him/her to relate the results to his/her schoolwork, achievement in a certain subject or school grade, course study or possible career choice. An SHI is not a psychological or psychometric instrument, and can therefore be used by any individual.

In some instances SHI's have clear advantages over standardized instruments. They can, for instance, be used in environments that have a shortage of trained persons who can help learners make career choices Although not as dependable as standardized psychometric tests, they can supply "clients" with workable suggestions with regard to educational and career choices. They are not as sensitive to teacher-learner ratios as standardized instruments, and can supply virtually immediate feedback to the user on the basis of his/her own decisions. Frequent application of SHI's helps learners gain mastery of life-skills and knowledge. SHI's are also economic, cost-effective, culture- and race-bias free, they demythologize test procedures and can be administered by "ordinary" regular teachers; they encourage self-exploration, are instrumental in integrating self and career knowledge, and supply the outcomes in a readily digestible way (Jacobs et al., 1988:219).

\section{Criteria for self-help instruments}

South African conditions dictate that certain criteria be met by instruments administered to learners (cf. South Africa, Department of Education, 1995:4). These criteria include avoidance of prejudice, Eurocentrism, racism, cultural dominance and bias, test bias, the hazy myths surrounding professional testing, excessive knowledge of intimate personal particulars and teacher dominance because of the possession of such knowledge. On the other hand, instruments should be innovative and appropriate for South African conditions (cf. COTEP, 1996), meet the vocational guidance needs of all learners and provide for cultural variation. Instruments should also accommodate the effects of previous race discrimination, gender bias, poverty and instability as a result of urbanization and other migration patterns, the needs of society and specific communities; the diversity of the school population; the geographical spread and the decision-making needs of learners. Instruments need to cover the following aspects: competence, racial background, attitude, gender differences, circumstances, labour values, vision - to mention only a few. 
A dilemma in South African vocational guidance - and a possible solution

Young South Africans can no longer be satisfied with mere theoretical knowledge of the self and of possible careers. Vocational guidance instruments should therefore be constructed and planned in such a way that they afford learners opportunities to take personal control of their lives. Instruments should provide learners of every age with knowledge and skills relating to self-image, self-control, self-confidence, interpersonal communication, stress control, recreation, health management, work ethics, decision-making, goal-setting, planning, readiness for change, hope for the future - and many more aspects of life. Mastery of such skills will enable them to take charge of their lives - and to become efficient and productive members of society (Marais, 1999:10-11).

Because of their advantages over standardized instruments, especially because of their highly personalized nature, SHI's are the obvious solution to the dilemma which we have outlined in section 1: they are immediately available, can be administered by any individual under all circumstances. Furthermore the results of SHI's are immediately available in readily understandable form, they are culturally sensitive and relevant, and can be adjusted and amended as conditions dictate

\section{Criteria for the construction and evaluation of SHI's}

Although SHI's are advocated as a possible solution to the vocational guidance dilemma in South Africa, the impression should not be created that the construction of SHI's is straightforward and uncomplicated. A number of stringent requirements have to be met for an SHI to be effective, i.e. to serve the desired purpose of culturally relevant personalized and individualized vocational guidance. Benecke (1980:67-89) and Jacobs et al. (1988:217) developed guidelines for the development of SHI's. The most important of these are as follows (in updated form in order to meet the needs of South Africans in the post-apartheid era):

- The SHI should supply the client with self-knowledge and personal capabilities, and assist him/her to realise his/her innate potential.

- The SHI should contribute to the realization of potentialities by asking about available opportunities, including careers.

- The SHI should connect and integrate personal and career knowledge.

- The SHI should inform the client/user about his/her personal life-view and value system, and relate these to values inherent in different careers. 
- The SHI should be limited in scope as well as in duration to prevent users from losing interest or becoming fatigued.

- The SHI should be inviting and interesting to users.

- The SHI should convey a clear sense of purpose, contain clear instructions; the language use should be unambiguous and easy to follow (appropriate for the age, gender and culture of the user).

- The SHI should be reliable and valid.

- The SHI should not be biased in any sense; it should, as far as possible, accommodate the needs of users in a multicultural society in the sense that cultural variables such as race, age, ethnic culture, gender, disability, urban/rural surroundings, religion, and sexual preference are treated as peripheral to the central focus of the SHI, viz. self and career knowledge for the purpose of an effective career choice.

- Users should experience the SHI as culturally relevant to themselves and their personal conditions.

- Users should experience all the items in the $\mathrm{SHI}$ as relevant and to the point.

- Every effort should be made that all users will interpret the different items in the SHI in the same way. This implies extensive research within and across cultural groupings.

- The items/questions in the SHI should comply with criteria such as appeal to the user, clear wording to prevent misunderstanding, conciseness, objectivity (i.e. not too personal), sensitivity, sensibility, classification, avoidance of the obvious, focus and purpose. Special care should be taken to ensure that semantic difficulties do not defeat the purpose of the SHI.

\section{Example of a self-constructed SHI}

Adherence to the above-mentioned criteria for SHI's will obviously result in the application of more than one SHI in a school, or even a class. The following are examples of items in a self-constructed SHI aimed at helping learners assess and understand their personal abilities, talents and aptitudes. The items have been constructed in such a way that respondents will not be able to complete them in the prescribed time. After the prescribed time, respondents will be aware of both their strong and weak points (Dewuld, 1999:76-81). The content matter as well as the 
A dilemma in South African vocational guidance - and a possible solution

difficulty level of the various items of an $\mathrm{SHI}$ should be appropriate for the age and school grade of the respondents

\subsection{Creativity}

\subsubsection{Creativity: creative ideas}

To what extent, and how effectively, can the respondent make use of creative ideas in problem-solving? This aspect of creative thinking is an important component of aptitude and talent though extremely difficult to measure. The respondent can be requested to perform the following task within the limit of 3 minutes:

\section{Example:}

Design as many postage stamps as possible, the various motifs and designs of which should depict the advent of democratic government in 1994. (Supply an example, e.g. a 45c stamp with a photograph of a smiling ex-president Nelson Mandela appearing on it.)

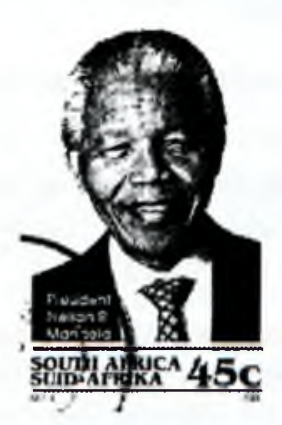

or:

Design as many stamps as you can in 3 minutes in which you depict the various aspects of South Africans' struggle against AIDS

Self-assessment: How did I fare? (Mark one of the following:)

\begin{tabular}{lccc} 
Extremely unsatisfactory & $:$ & 1 \\
Unsatisfactory & $:$ & 2 & \\
Fair & $:$ & 3 & \\
Well & $:$ & 4 & \\
Very well & $:$ & 5 & \\
\hline 486 & & & Koers $65(4) 2000 \cdot 477-493$
\end{tabular}




\subsubsection{Creativity: Verbal expression}

To what extent can respondents express feeling? To assist respondents in assessing their verbal capacities, they can be requested to perform the following task within 3 minutes:

\section{Example:}

Construct as many short sentences as possible in which you express or portray the feeling of hunger. (Supply an example, e.g. I feel faint with hunger, or: I feel like having been on a hunger strike for a month, or: my stomach grumbles).

or:

Construct sentences to express and portray feelings of fear (or anxiety, or uncertainty, etc.).

Apply the same self-assessment instrument (see 6.1.1 Creativity: creative ideas).

\subsubsection{Creativity: numerical ability}

To what extent are respondents able to manipulate numerical data? To assist respondents in assessing this ability they can be requested to arrange the following numerals in various sequences, and to supply the principles according to which this is done:

\section{Example:}

2, 3, 4, 6, 17, 23, 36. (Supply an example, e.g. 3, 17, 23 - uneven numbers; $17,23,36$ double digit numbers.)

or:

Use any 3 of the following numerals in various combinations: $1,2,3,4,5$, $6,10,11,15,60,111,600$ (two minutes).

Self-assessment. as before.

\subsection{Speed}

\subsubsection{Speed of thinking: symbols}

The speed at which one thinks and can react forms an important aspect of aptitude and ability. Set the following task: 
The following is a long set of symbols. Some symbols are directly followed by an "empty" 0 . See how many of these "empty" 0's you can strike through in 30 seconds.

Example: $\quad$ ex

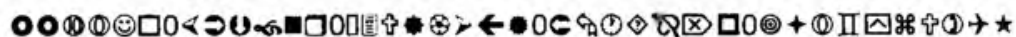

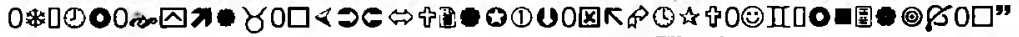

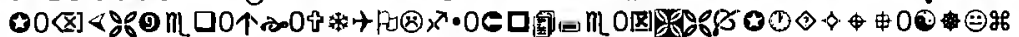

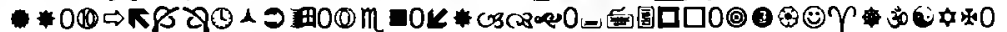

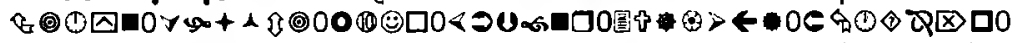
(2)+口I⿴囗十心O+

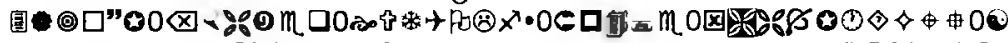

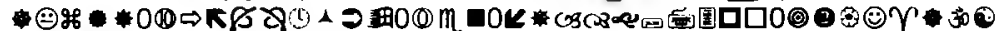

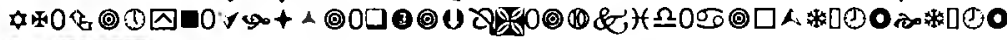
$0 \approx \pi \times 0 \square$

Self-assessment as before

\subsubsection{Speed of thinking: verbal}

Set the following task (or something similar):

\section{Example:}

Underline all the four-letter words in the following sequence (you have 30 seconds):

WITHALLMANNERCOMENOWDOGSANDLAMBDOGSFALLSBUMPS

Self-assessment. as before

\subsubsection{Speed of thinking: numeral}

Set the following task (or something similar):

Add as many of the following figures as you can in 30 seconds:

$\begin{array}{lll}5+4+3= & 7+12+5= & 4+9+2= \\ 2+8+14= & 7+8+15= & 9+3+19= \\ 12+6+1= & 3+13+6= & 10+7+6= \\ 8+2+6= & 11+2+6= & 4+7+18= \\ 8+5+9= & 6+17+5= & 8+8+16=\end{array}$

Self-assessment as before. 


\subsection{Attentiveness}

These are memory tests

\subsubsection{Aftentiveness: verbal comprehension}

Set the following task:

\section{Example:}

Read the following story, and then answer the questions without referring to the text again. (How good is your memory?) (A short story of 50-60 words is presented, and approximately 5 questions, of which the answers can be found in the story have to be answered. Note that the level of the story [content and vocabulary] as well as of the answers has to be compatible with the age, language proficiency, culture, and so forth of the respondents.)

\section{Self-assessment. as before}

\subsubsection{Attentiveness: numerals}

Set a task like the following:

\section{Example:}

The following table consists of train numbers in the left-hand column, and their departure times in the second column. In column three the numbers of the trains are presented in another sequence. See whether you can find all the corresponding departure times in the right-hand column. You have two minutes. Do not look at the first two columns once you start filling in column number 4 !

Self-assessment. as before.

\subsection{Capacity to process}

The ease with which complex data can be processed is an indicator of the presence of considerable talent in respondents.

\subsubsection{Capacity to process: verbal}

Set a task like the following:

Respondents are required to read a short paragraph (100-150 words) about the intricate and involved relationships/kinship in an extended family (nephews, nieces, cousins, aunts, in-laws, grandparents and grandchildren, etc.) They are then requested to determine the relation- 
A dilemma in South African vocational guidance - and a possible solution

ship/kinship between two or three persons from the available data in one minute or less.

Self-assessment. as before.

\subsubsection{Capacity to process: numeral}

Set a task like the following:

Respondents are required to perform relatively difficult computations like $2.25 \times 8$, and then to select the correct answer from a set of multiple choices. As many as possible calculations and computations of this nature should be done in two minutes or less.

Self-assessment as before.

\section{Discussion}

As was intimated in 6 above, the 11 items presented above are concentrated only on ability, talent and attitude, and should be seen as mere exemplars of items that can be devised by the counsellor/teacher to assist learners to assess the extent and quality of their own aptitude etc The number of items can be extended and can be formulated in such a way as to concentrate on specific aspects of respondents' ability, personality, interests and so on. Care should, however, be taken not to overburden respondents, thus tiring them and causing them to lose interest and to respond inaccurately or carelessly. The purpose of an SHI is to guide learners to greater self-understanding, and the number of items as well as their level of difficulty should be appropriate to the age, grade, sexual preference, culture etc. of the learners. Although most items should be appropriate for the majority of learners, teachers/ counsellors may find themselves in situations where certain items will have to be "custom made" for specific learners.

The self-assessment scale that follows after each item is expressly for the personal use of the respondent/learner. A respondent, assured of the confidentiality of his/her response, can therefore be blatantly honest with himself/herself. The respondent can assess his/her own ability on an item for item base, or can add the results of all items to get an overall picture of his/her ability, aptitude, personality and so on. Teachers/ counsellors should respect the private and confidential nature of an SHI, but should be available for advice, assistance, guidance and counselling - should the respondent wish to share the results of an item or of the whole SHI with him/her. 
SHI's are essentially self-devised instruments and their construction demands a great deal of skill on the part of the counsellor/teacher. It can be expected that a degree of trial and failure will occur in constructing SHI's, especially in unique cases, e.g. mentally or physically retarded learners, immigrants, members of minority culture groups, gays and lesbians, and so on. The results of an SHI cannot be generalized; it is a highly individualized assessment of aspects of a unique individual. Despite the highly unique and individualized nature of SHI results, the upshot can be used for a profound and penetrating discussion on the needs and requirements of the individual whose results are being used as the basis of a discussion or counselling.

As was indicated in previous paragraphs, SHI's do not require highly trained practitioners (although they do require a great deal of skill based on experience), and are relatively inexpensive to develop and administer. Because of this characteristic of SHl's, they are extremely suitable for application in poorer communities. SHl's can be applied repeatedly, but will need updating from time to time, and will also need adjustment as the learner population develops (for instance, become more sophisticated because of exposure to higher level mass media, like television, radio and newspapers).

\section{Concluding remarks}

The criteria and guidelines presented above emphasize the fact that the construction of SHI's is by no means a less onerous and responsible task than that of standardized tests. However, SHI's are more adaptable to the particular circumstances of the user, and with the necessary care they can be used to avoid bias, prejudice and stereotyping which are a constant threat in the implementation of other instruments. South African conditions call for innovative solutions. SHI's seem to be a solution for the dilemma in vocational guidance that had been created by South Africa's unfortunate past.

\section{Bibliography}

BARNARDT, H.V.D W. 1971. 'n Ondersoek na die invloed van die voorligtingsdienste op die studierigting van leerders aan die Afrikaanse hoër onderwysinrigtings in Transvaal. Potchefstroom : PU vir CHO. (Verhandeling - M Ed.)

BENECKE, F.C. 1980. 'n Pedagogies-verantwoorde ontwerp van vraelyste vir evaluering van beroepskennis. Pretoria : UP. (Verhandeling - M.Ed.)

CHARTRAND, J.M \& ROSE, M L. 1996. Career interventions for at-risk populations. Incorporating social cognitive influences. The Career Development Quarterly, 44:341-350

CLEARLY, T.A. 1968 Test bias: Prediction of grades of Negro and White learners in integrated colleges. Journal of Educational Measurement, 5:115-124. 
COMMITTEE ON TEACHER EDUCATION POLICY (COTEP) 1996. Norms and standards for teacher education. February.

COTEP, see Committee on Teacher Education Policy

DEWULD, M. 1999. De 8 talenten van de mens. Goed Gevoel: 4, April

FAGAN, T.K. \& WISE, P S. 1994 School psychology. London : Longman.

FOUAD, M.A. 1993. Cross-cultural vocational assessment Career Development Quarterly, 42:4-13

FOUAD, M.A. \& BINGHAM, DR. 1995. Career counseling with racial and ethnic minorities (In Walsh, W.B. \& Osipow, S.H., eds. Handbook of vocational psychology. Mahwah, J.J. : Erlbaum p. 331-336.)

GIBSON, R.L \& MITCHELL, M.H 1995. Introduction to counseling and guidance. Ohio : Prentice Hall.

GOUDZWAARD, B 1997. Towards a future of care. (In Lambert, 1. \& Mitchell, S. eds. The crumbling walls of certainty. Sydney: Centre for the Study of Australian Christianity p. 40-49.)

GYSBERS, N.C., HEPNER, M.J \& JOHNSTON, J.A. 1998 Career counselling Boston : Allyn \& Bacon.

HACKETT, G. \& BYARS, A.M. 1996 Social cognitive theory and the caree development of African American women. The Career Development Quarterly, 44:322-338, June.

HERNÁNDEZ, T.J. \& MORALES, N.E 1999. Career, culture and compromise Career development Experiences of Latinas working in Higher Education. The Career Development Quarterly, 48:45-57, Sept

HERR, E.L. \& CRAMER, S.H. 1996. Career guidance and counseling through the lifespan. New York: Harper Collins College Publishers. HSRC

see Human Sciences research Council

HUMAN SCIENCES RESEARCH COUNCIL. (HSRC) 1989. Handbook for the use of psychological and scholastic tests of IQER and the NIPR. Pretoria : Gutenberg Book Printers

ISAACSON, L.E. 1984. Basics of career counselling. Boston : Allyn \& Bacon

JACOBS, CD. 1981. Persoonsverkenning in beroepsoriëntering Pretoria : UP (Verhandeling - M.Ed.)

JACOBS, C D., VAN JAARSVELD, N.H. \& VON MOLLENDORF, JW 1988. Beroepsvoorligting vir die hoër- en laerskool: 'n Handleiding vir die onderwyser Pretoria : Konsensus Uitgewery

JOUBERT, C.J. 1983. Evaluering van die hedendaagse beroepsorienteringsteorie en -praktyk Nuwe reeks no. 195. Pretoria : Universiteit van Pretoria.

KORMAN, M. 1974. National conference on levels and patterns of professional training in psychology. American Psychologist, 29:441-449

KOK, A 1995. Die ontwerp van 'n digotome program tot beroepskeuse. Potchefstroom : PU vir CHO. (Proefskrif - Ph.D.)

KRUGER, H.B. 1995. Skoolvoorligting. Departement Sentrale Publikasies. Potchefstroom : $\mathrm{PU}$ vir $\mathrm{CHO}$

LANDSBERG, S. 1996. Career role modelling as method in career education Potchefstroom : PU for CHE. (Dissertation - Ph D.)

LIEBETRAU, J.P., red 1987. Handleiding vir algemene skoolvoorligting. Johannesburg : Perskor.

MARAIS, J.L. 1999. Beroepsvoorligting in die nuwe millenium: Belangrike fokuspunte Polchefstroom. PU vir $\mathrm{CHO}$. (Reeks H. Inougurele rede no. 157.) 
J.L. Marais \& J.L. van der Walt

NAUDE, G.N. \& BODIBE, R.C 1986. Manual for guidance teachers. Pretoria Acacia.

PARSONS, E. 1909. Choosing a vocation. Boston : Houghton-Mifflin

RAAD VIR GEESTESWETENSKAPLIKE NAVORSING (RGN). 1984. Skoolvoorligtingstelsels in die RSA. Verslag 0-158. Pretoria

SINE, T. 1997. Shifting education into the future tense. (In Lambert, I. \& Mitchell, S., eds. The crumbling walls of certainty. Sydney : Centre for the Study of Australian Christianity. p. 25-39.)

SKILLEN, J W. 1987 Changing assumptions in the public governance of education What has changed and what ought to change. (In Boer, R.A., ed. Democracy and the renewal of public education. Grand Rapids : Eerdmans. p 86-115.)

SOUTH AFRICA. DEPARTMENT OF EDUCATION 1995. Interim core syllabus for guidance. Pretoria : Government Printer

SOUTH AFRICA. DEPARTMENT OF EDUCATION 1997. Quality education for all Pretoria : Government Printer.

SOUTH AFRICA. DEPARTMENT OF EDUCATION. 1998. Green paper on education and training. Pretoria : Government Printer

SUE, D.W. \& SUE, D. 1990. Counseling the culturally different. New York : Wiley

VAN DER WESTHUIZEN, J.G.L., MARAIS, J.L. \& KRUGER, H B 1999. Handleiding vir die gebruik van sielkundige toetse, diagnostiese toetse en selfhelpinstrumente as hulpmiddels by skoolvoorligting. Potchefstroom : Estmar-Uitgewers.

VAN DYK, J. 1997. Letters to Lisa. Conversations with a Christian teacher Sioux Center : Dordt Press

WALSH, B.J. 1997. Education in precarious times. (In Lambert, I. \& Mitchell, S, eds The crumbling walls of certainty. Sydney : Centre for the study of Australian Christianity. p 8-24.)

\section{Key concepts:}

criteria for self-help instruments example of self-help instruments self-help instruments (SHI's) vocational guidance

\section{Kernbegrippe:}

beroepsvoorligting

kriteria vir selfhelpinstrumente

selfhelpinstrumente (SHI'e)

voorbeelde van selfhelpinstrumente 